\title{
DURABILITY OF FRP/WOOD BONDS GLUED WITH EPOXY RESIN
}

\author{
OBSTOJNOST FRP/LESNIH SKLOPOV, LEPLJENIH Z EPOKSI \\ SMOLO
}

\author{
Jan Vaněrek, Milan Šmak, Ivo Kusák, Petr Misák \\ Brno University of Technology, Faculty of Civil Engineering, Veveři 95, 60200 Brno, Czech Republic \\ vanerek.j@fce.vutbr.cz \\ Prejem rokopisa - received: 2016-11-18; sprejem za objavo - accepted for publication: 2017-04-20
}

doi:10.17222/mit.2016.321

\begin{abstract}
The paper describes the properties of FRP/wood bonds, made of different wood species commonly used in the timber industry within Central Europe (oak, spruce, pine and larch). An FRP fabric (glass-fiber-reinforced polymer - GFRP, carbon-fiber-reinforced polymer - CFRP) was applied as the reinforcement. The durability of all the reinforced FRP/wood assemblies was verified with short-term exposure tests following the tensile-shear-strength and wood-failure criteria for the shear area of a single-lap joint. To precisely define the effect of the mechanical interlocking mechanism of the bond, analyses of porosity and surface roughness, and SEM were performed.

Keywords: durability, epoxy, FRP, wood adherend
\end{abstract}

Članek opisuje lastnosti FRP/lesnih sklopov, narejenih iz različnih vrst lesa, ki se običajno uporablja v lesni industriji v Srednji Evropi (hrast, jelka, bor, macesen). FRP-materiali (polimeri, ojačani s steklenimi vlakni - angl. GFRP, polimeri, ojačani z ogljikovimi vlakni, angl. CFRP) so bili uporabljeni za ojačanje. Obstojnost vseh FRP/lesnih sklopov so preverjali s kratkotrajnimi strižnimi preizkusi. Kriterij je bil površina strižnega preloma na enojni prekrivni ploskvi med FRP in lesom. Da bi lahko natančno definirali mehansko trdnost spoja, so izvedli analize poroznosti, površinske hrapavosti in SEM-analize.

Ključne besede: trajnost, epoksi, FRP, lepljivost lesa

\section{INTRODUCTION}

The main purpose of the FRP usage with timber in the construction industry is generally to improve the stiffness/strength of reinforced items without any influence on their service life or any environmental impact. From the perspective of the timber-reinforcement process, the optimum dimensional stability during moisture changes in wood should be one of the most important criteria for such joints.

Different studies were made for the FRP/wood bond durability using different types of adhesives. The optimum results of adhesion were achieved using formaldehyde-based adhesives; ${ }^{1-3}$ different, contrary results were found using epoxy resins..$^{4,5}$ The results ${ }^{1}$ for the epoxy resins showed an inability to reach the requirement for a cohesive failure of $80 \%$ (in wood) after an exposure to cyclic hygrothermal conditions. Moreover, positive results were found using priming treatments (hydroxymetyl resorcinol - HMR; resorcin-fenol - RF; hexamethylolmelamin metyl ether MME) before the gluing process. ${ }^{2}$ The durability of FRP/wood joints using epoxy has not been completely established. Therefore, the final aim of this experiment was to establish the durability aspect of such joints. The focus was on the observation of the wood adhering parameters having a significant impact on the mecha- nical interlocking process to understand the impact of mechanical interlocking on the joint durability.

\section{EXPERIMENTAL PART}

\subsection{Materials}

Carbon, glass or aramid are common reinforcementfiber materials used for external polymer-composite systems known as fiber-reinforced polymers (FRPs). Reinforcing of wood with FRP lamellas/fabrics could be applied without any restriction regarding the wood species. To evaluate the influence of wood species, the experiment used glass-fiber-reinforced polymer (GFRP) and carbon-fiber-reinforced polymer (CFRP) fabrics applied to different wood adherents. Oak (Quercus robur), spruce (Picea abies), pine (Pinus sylvestris) and larch (Larix decidua) with a uniform thickness of $25 \mathrm{~mm}$ were chosen. The fabrics with carbon fibers (Tyfo SCH-41, FYFE Co.) with a width of $1.0 \mathrm{~mm}$ and the GFRP with glass fibre (Tyfo-SEH-51A, FYFE Co.) with a width of $1.3 \mathrm{~mm}$ were used. As the adhesive, the epoxy resin TYFO $S$ (diglycidyl ether of bisphenol-A, DGEBA) with an amine hardener was used. Pre-treatment including penetration of the wood surface to ensure stabilization of wood cells $\left(200 \mathrm{~g} / \mathrm{m}^{2}\right)$ was applied. Similarly, the FRP fabrics were saturated with epoxy resin $\left(400 \mathrm{~g} / \mathrm{m}^{2}\right)$ on both sides. After $30 \mathrm{~min}$ of such 


\section{J. VANĚREK et al.: DURABILITY OF FRP/WOOD BONDS GLUED WITH EPOXY RESIN}

pre-treatments, the FRP strips were applied to the wood surface. After $24 \mathrm{~h}$ of the epoxy curing process, the final layer of the epoxy matrix in the amount of $200 \mathrm{~g} / \mathrm{m}^{2}$ was also applied without any pressure. All the applications were carried out at a laboratory ambient temperature of $20{ }^{\circ} \mathrm{C}$. To ensure the post-curing process, the assemblies were exposed to a constant temperature of $60{ }^{\circ} \mathrm{C}$ for $72 \mathrm{~h}$. After the post-curing process, the test samples of $20 \mathrm{~mm} \times 8 \mathrm{~mm} \times 150 \mathrm{~mm}$ with 3 -mm-thick notches in the wood were adhered to the fabrics and the CFRP or GFRP layers were made, defining the shear area.

\subsection{Tensile-shear-strength testing}

The FRP/wood specimens were subjected to accelerated tests, exposing them to all the climatic treatments and different hygrothermal conditions (classes A2-A5, specified in ČSN EN 302-1, Table 1). Tensile-shear tests were performed on the test specimens, for each condition class, and a total of 12 test samples were used. The tests were performed on a Testometric M350-20CT machine (Testometric Company Ltd., UK), digitally recording the test progress at a crosshead speed of $1 \mathrm{~mm} / \mathrm{min}$. As an additional evaluation of the bond durability, the wood failures within the shear area (rounded to the nearest value in multiples of $10 \%$ ) were visually assessed.

Table 1: Types of exposure treatments prior to the tensile-shear testing

\begin{tabular}{|c|c|c|}
\hline Treatment & Climatic treatment & Specification \\
\hline A1 & Standard climate & $7 \mathrm{~d} 20^{\circ} \mathrm{C} / 65 \%$ \\
\hline A2 & $\begin{array}{l}\text { Immersion in cold } \\
\text { water }\end{array}$ & $\begin{array}{c}7 \mathrm{~d} 20{ }^{\circ} \mathrm{C} / 65 \% \\
4 \mathrm{~d} \text { in water }\left(15 \pm 5{ }^{\circ} \mathrm{C}\right) \\
\text { Tested in a wet state }\end{array}$ \\
\hline A3 & $\begin{array}{l}\text { Immersion in cold } \\
\text { water }\end{array}$ & $\begin{array}{c}7 \mathrm{~d} 20^{\circ} \mathrm{C} / 65 \% \\
4 \mathrm{~d} \text { immersion in water } \\
\left(15 \pm 5{ }^{\circ} \mathrm{C}\right) \text {, conditioning at } \\
20{ }^{\circ} \mathrm{C} / 65 \% \\
\text { Tested in a dry state }\end{array}$ \\
\hline A4 & $\begin{array}{l}\text { Immersion in } \\
\text { boiling water }\end{array}$ & $\begin{array}{c}7 \mathrm{~d} 20^{\circ} \mathrm{C} / 65 \% \\
6 \mathrm{~h} \text { in boiling water } \\
2 \mathrm{~h} \text { immersion in water } \\
\left(15 \pm 5^{\circ} \mathrm{C}\right), \\
\text { Tested in a wet state }\end{array}$ \\
\hline A5 & $\begin{array}{l}\text { Immersion in } \\
\text { boiling water }\end{array}$ & $\begin{array}{c}7 \mathrm{~d} 20{ }^{\circ} \mathrm{C} / 65 \% \\
6 \mathrm{~h} \text { in boiling water } \\
2 \mathrm{~h} \text { immersion in water } \\
\left(15 \pm 5^{\circ} \mathrm{C}\right) \\
7 \mathrm{~d} \text { conditioning at } \\
20{ }^{\circ} \mathrm{C} / 65 \% \\
\text { Tested in a dry state }\end{array}$ \\
\hline
\end{tabular}

\subsection{Microstructural analysis}

To assess the effect of mechanical interlocking as a possible aspect of a bond, the microstructures of all the tested wood adherents were analyzed. The sizes of the main structural elements of the transverse wood microtome samples were assessed. Electron scanning microscopy provided an accurate evaluation of a failed bond based on the loss of adhesion.

\subsection{Wood-surface-roughness analysis}

The surfaces of all the tested wood adherents were scanned using confocal laser microscopy in both the optical and confocal mode. The automatic microscope mode was used to determine the highest and lowest point of the relief of a scanned area. The number of optical sections depended only on the wood, assuming that the other parameters such as magnification and the illumination mode (laser or optical light) remained unchanged. Alternatively, the number of optical sections depended on the illuminated thickness of the wood. Optical cuts from 40 to 60 in the optical mode and from 70 to 90 in the confocal mode were evaluated. The purpose of this analysis was to see if the different surface roughness of each wood species has an impact on the final durability of a FRP/wood bond. The parameters of mean quadratic heights (SRq, SPq) and mean arithmetic heights (SRa, $\mathrm{SPa}$ ) were assessed in five different appointed places for each tested wood. Surface roughness parameters SRa, $\mathrm{SPa}, \mathrm{SRq}$ and $\mathrm{SPq}$ are based on one-dimensional parameters $\mathrm{Ra}$ (the arithmetic mean of roughness), $\mathrm{Pa}$ (the arithmetic mean of height of a curve profile), $\mathrm{Rq}$ (the root mean square roughness), $\mathrm{Pq}$ (the root mean square height of a curve profile). The calculation of these one-dimensional parameters is specified in ČSN EN ISO 4287 and the conversion into surface parameters was calculated based on the data acquired from two perpendicular directions.

\subsection{Porosity}

The pore size and pore distribution within all the tested wood specimens were evaluated with mercury porosimetry using the PASCAL 140/240, Thermo Finnigan equipment. Wood samples with a volume of approx. $0.75 \mathrm{~cm}^{3}$ were used. To avoid an overestimation of the portion of smaller pores, a gradual increase in the rate of pressure during the process was chosen.

\section{RESULTS}

\subsection{Tensile-shear-strength testing}

The mean strength values obtained are shown in Figures 1a to 1d; it is clear that the sets of dry-wet cycling ageing tests show a reduction in the joint strength. The most significant strength reduction in the dry state for both FRP materials resulted from the specimens subjected to both exposure treatments, providing a significant hygrothermal-stress concentration in the bond line.

To compare the test results, variance tests (ANOVA) were analyzed. The influence of the type of exposure was tested using the one-way ANOVA. Based on this analysis, the tensile strength is significantly influenced by the type of exposure. In addition, the two-way ANOVA was used when both the type of exposure and the type of reinforcement were factors. The purpose of 
J. VANĚREK et al.: DURABILITY OF FRP/WOOD BONDS GLUED WITH EPOXY RESIN

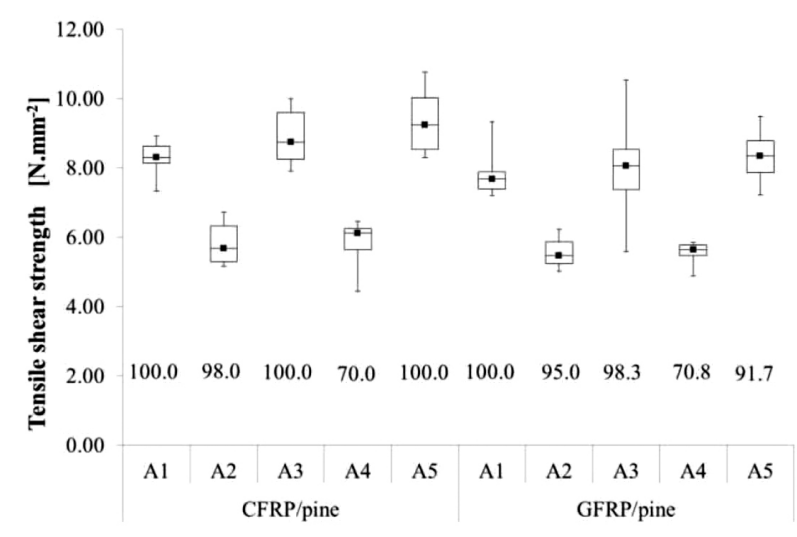

Type of exposure according to EN 302-1

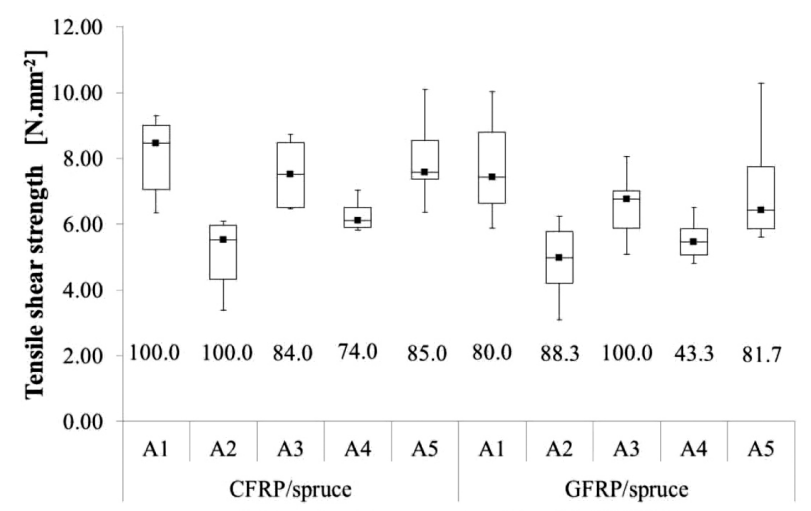

Type of exposure according to EN 302-1

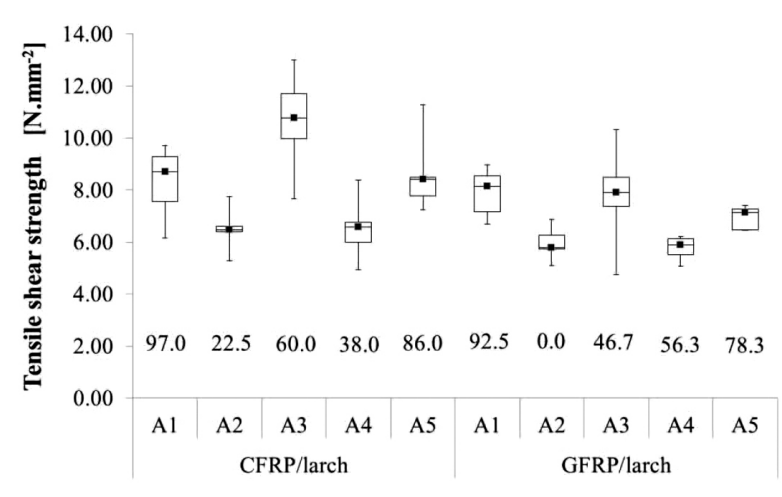

Type of exposure according to EN 302-1

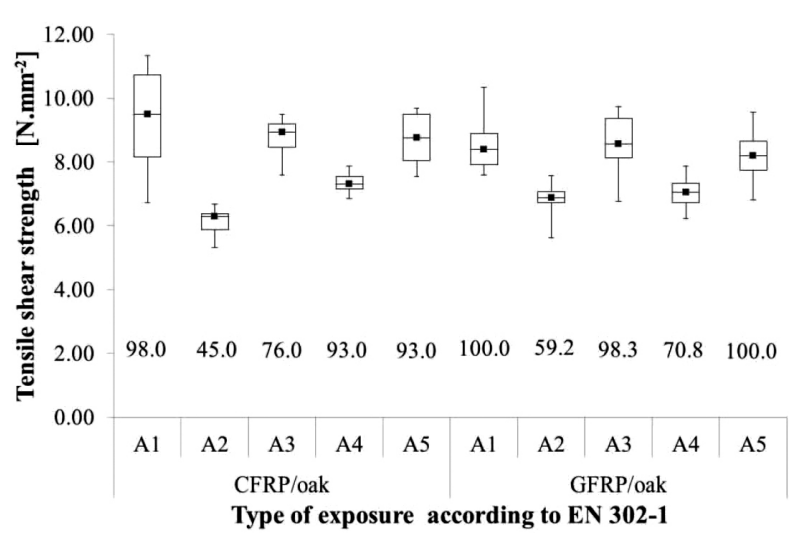

Figure 1: Mean tensile-shear strengths of the samples tested after the exposure to climatic treatment according to EN 302-1; $\mathbf{\square}$ denotes the mean value; the box plot - rectangle shows the interquartile range (IQR) with the median depicted within the box; for each exposure, the value of wood failure is stated

Table 2: Mean values of the wood-element size proportion of the used wood species

\begin{tabular}{|c|c|c|c|c|c|c|c|c|}
\hline & \multicolumn{8}{|c|}{ Size (diameter) of wood elements $(\mu \mathrm{m})$} \\
\hline & \multicolumn{5}{|c|}{ Lumina } & \multicolumn{3}{|c|}{ Cell-wall thickness } \\
\hline & \multicolumn{2}{|c|}{ tracheids } & \multicolumn{2}{|c|}{ vessels } & \multirow[t]{2}{*}{ libriform } & \multicolumn{2}{|c|}{ tracheids } & \multirow[t]{2}{*}{ libriform } \\
\hline & early wood & late wood & early wood & late wood & & early wood & late wood & \\
\hline Pine (Pinus sylvestris) & 26.1 & 9.7 & & & & 6.0 & 11.7 & \\
\hline Larch (Larix decidua) & 30.7 & 10.1 & & & & 4.7 & 9.2 & \\
\hline Spruce (Picea abies) & 31.2 & 10.3 & & & & 4.0 & 8.9 & \\
\hline Oak (Quercus robur) & & & 245.0 & 41.9 & 9.0 & & & 4.0 \\
\hline
\end{tabular}

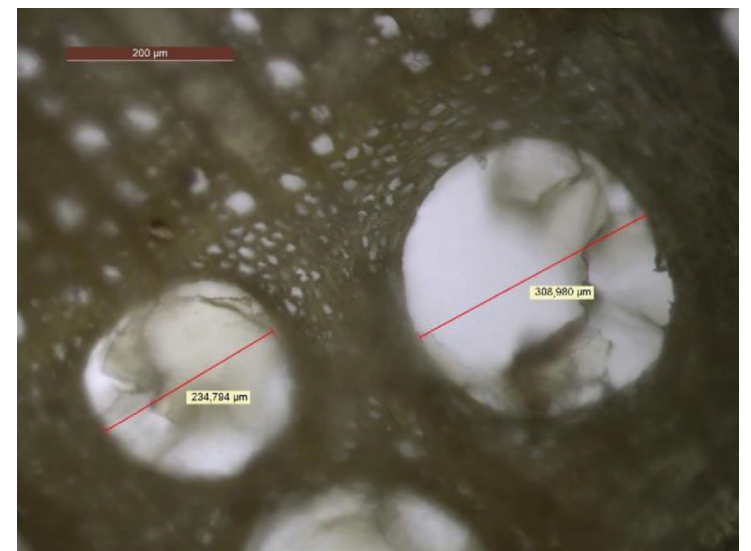

Figure 2: Cross-section of oak wood, apparent vessel elements and libriform cells, magn. $100 \times$

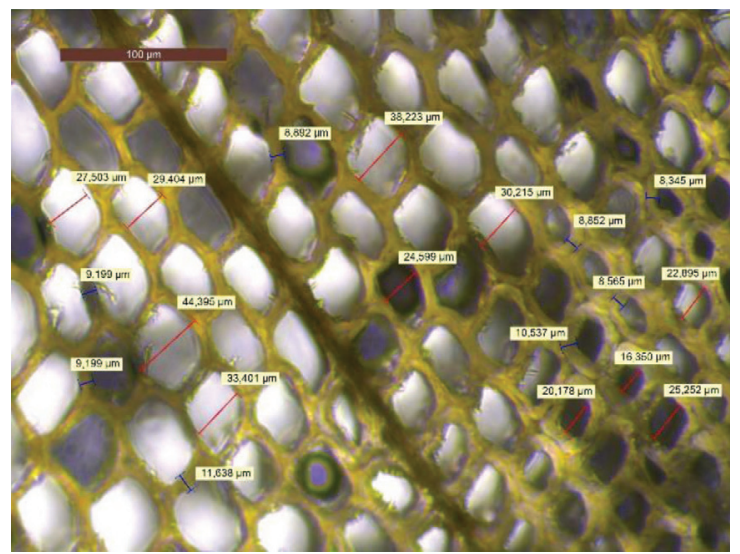

Figure 3: Cross-section of an early part of the annual ring of spruce wood, magn. 200x 


\section{MATERIALI IN TEHNOLOGIJE/MATERIALS AND TECHNOLOGY (1967-2017) - 50 LET/50 YEARS}

\section{J. VANĚREK et al.: DURABILITY OF FRP/WOOD BONDS GLUED WITH EPOXY RESIN}

this was to establish the individual influences of these factors and the interaction between them. The results of the two-way ANOVA show that each factor is statistically significant for the tensile strength, but the interaction between the factors is not significant. All the statistical tests were carried out at a significance level of 0.05 .

\subsection{Microstructural analysis}

Results of the size-distribution evaluation did not show any significant difference between the coniferous species; the biggest size of the cell-wall thickness was found for the pine species, concurring with the smallest size of the pores (lumina) of tracheid elements. Details of all the observed elements are shown in Table 2. The photomicrographs of the hardwood and conifer species with the size measurements are shown in Figures 2 and 3 .

\subsection{Wood-surface-roughness analysis}

A comparison of the results of the profile parameters (SPa, SPq) indicates deviations from the interspaced centerline of the test surface; the highest deviations were detected on the oak surface, arising from the existence of open vessel elements (Figure 5). The smallest deviation was found on the pine; the drop of the profile-parameter value for the pine was lower by almost $50 \%$ compared to the other coniferous woods.

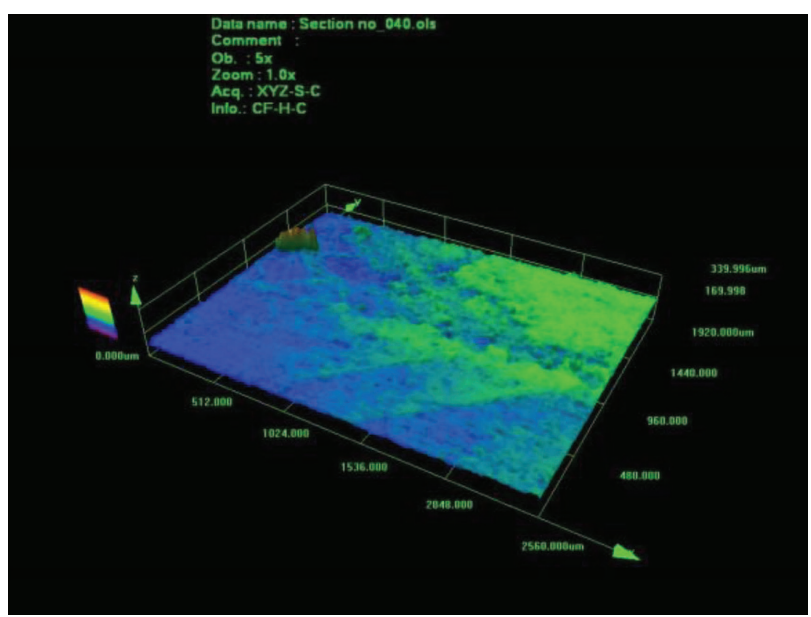

Figure 4: Surface relief of the pine sample used for calculating square roughness parameters (magn. 120×; area of $2560 \mu \mathrm{m} \times 1920 \mu \mathrm{m}$ )

Table 3: Values of selected roughness parameters of used wood species obtained with confocal microscopy

\begin{tabular}{|c|c|c|c|c|c|c|c|c|}
\hline \multirow{2}{*}{$\begin{array}{c}\text { Wood } \\
\text { species }\end{array}$} & \multicolumn{2}{|c|}{ Mean values and S. D. of roughness parameters } \\
\cline { 2 - 9 } & \multicolumn{2}{|c|}{ SPa } & \multicolumn{2}{c|}{ SRa } & \multicolumn{2}{c|}{ SRq } & \multicolumn{2}{c|}{ SPq } \\
\hline Pine & 9.14 & 1.20 & 5.82 & 0.18 & 8.00 & 0.41 & 12.31 & 1.29 \\
\hline Oak & 42.89 & 9.20 & 9.66 & 1.04 & 14.77 & 1.73 & 53.68 & 10.35 \\
\hline Larch & 19.95 & 2.20 & 8.05 & 0.95 & 11.22 & 1.52 & 24.84 & 3.18 \\
\hline Spruce & 17.41 & 3.03 & 7.47 & 0.63 & 11.20 & 1.26 & 22.95 & 3.51 \\
\hline
\end{tabular}

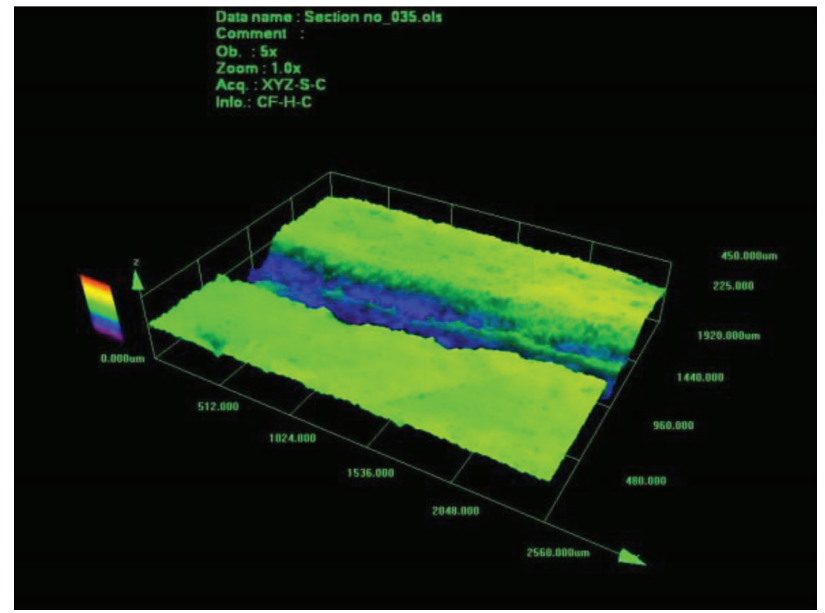

Figure 5: Surface relief of the pine sample used for calculating square roughness parameters (magn. 120×; area of $2560 \mu \mathrm{m} \times 1920 \mu \mathrm{m}$ )

The achieved values of the roughness parameters (SRa, SRq), where the longwave part is eliminated, showed the highest values of the roughness for the oak sample; the highest decrease of nearly $40 \%$ was observed for the pine sample, compared to the other softwood species. All the achieved values are shown in Table 3.

\subsection{Porosity}

Among all the other parameters, porosity has the most significant influence on the impregnability of

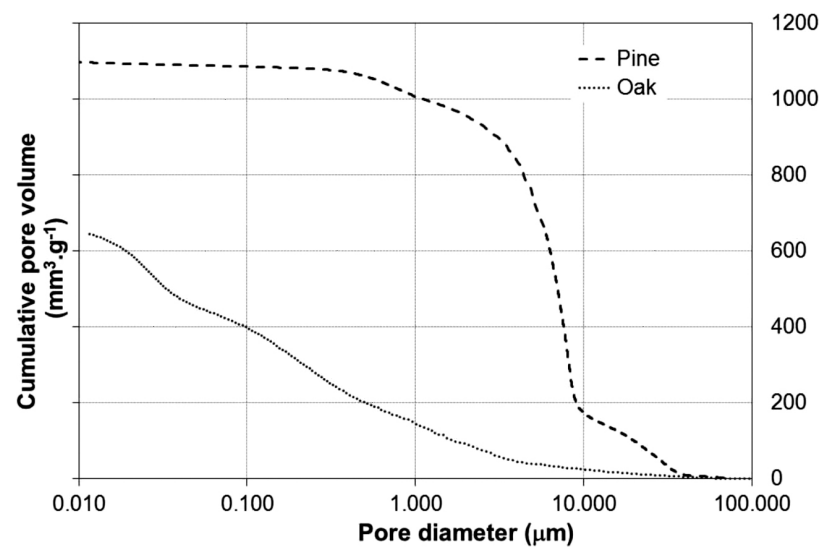

Figure 6: Cumulative pore volume as a function of the pore diameter of softwood and hardwood species

Table 4: Achieved results of mercury porosimetry of tested wood samples

\begin{tabular}{|c|c|c|c|c|}
\hline $\begin{array}{c}\text { Wood } \\
\text { species }\end{array}$ & $\begin{array}{c}\text { Total } \\
\text { porosity }\end{array}$ & $\begin{array}{c}\text { Specific } \\
\text { density }\end{array}$ & $\begin{array}{c}\text { Bulk } \\
\text { density }\end{array}$ & $\begin{array}{c}\text { Cumulative } \\
\text { pore } \\
\text { volume }\end{array}$ \\
\cline { 2 - 5 } & $\%$ & $\mathrm{~kg} \mathrm{~m}^{-3}$ & $\mathrm{~kg} \mathrm{~m}^{-3}$ & $\mathrm{~mm}^{3} \mathrm{~g}^{-1}$ \\
\hline Oak & 47.6 & 1410.0 & 738.6 & 644.7 \\
\hline Larch & 54.0 & 1518.4 & 699.2 & 771.6 \\
\hline Pine & 60.3 & 1381.1 & 549.0 & 1097.3 \\
\hline Spruce & 62.8 & 1423.6 & 528.9 & 1188.1 \\
\hline
\end{tabular}


wood. Consequently, the bulk density and specific density for each tested sample were established from the other parameters. The resulting values are shown in Table 4, confirming the presumption of a decreasing total porosity despite the increasing bulk density. The cumulative pore-volume curves as a function of the pore diameter of oak (hardwood) and pine (softwood) are shown in Figure 6.

\section{DISCUSSION}

\subsection{Tensile-shear-strength testing}

A stronger effect of the thermal exposure ensuring the hygrothermal exposure for condition classes A4 and A5 compared to the exposure without a thermal effect (A2, A3) was not proven (Table 5).

Regarding the type of fabrics, there was no indication of any dependency on the durability aspect. The requirements of the EN standard for strength limits (related to the beech/beech bond) for all the exposures were not exceeded by any of the tested samples. The most significant result of durability was achieved with the pine as an adherent when no losses in the strength occurred under all the severe exposures. Furthermore, the values of the cohesive failure expressed with a higher wood failure (WF) for the pine/FRP bonds supported this durability aspect. The values of the wood failure showed that the minimum limit of $80 \%$ was not reached for the dry test samples of larch as a softwood; also, the WF percentage dropped below the $80 \%$ criterion for the FRP/larch samples tested in a wet condition. Comparing the effects of the strength and wood-failure parameters, it can be clearly indicated that the more decisive criterion for the durability aspect shows exceptional values for the type of failure as shown for the larch/FRP bonds.

\subsection{Porosity}

The microscopy analysis of the main structural elements showed similar sizes of tracheids for all the softwood species; the highest porosity was established for spruce, the lowest for larch. But differences occurred between the results for the pore distribution as a function of the pore diameter. The differences occurred between the distributions of pores for the softwood species where the biggest drop in the distribution occurred for the pore diameters of $10 \mu \mathrm{m}$, contrary to the shape of the distribution curves for the oak as the ring-porous wood, which showed a consistent increase in the pore volume for pore diameters from $12 \mathrm{~nm}$ to $100 \mu \mathrm{m}$. The distribution of pore diameters for softwood is affected by the amount of tracheids elements, which form the main structure of softwoods. The lowest value of the porosity was established for the oak-wood sample; however, this had no effect on the final durability of the FRP/wood bond. Similar strength decreases were found when comparing the FRP/oak samples with the samples of the other wood species. The values of the pore distribution correlate with similar results, ${ }^{6}$ performed for the European wood species.

\subsection{Bond-line failure}

After the accelerated tests, the FRP/wood bond lines were assessed at the macroscopic and microscopic levels. At the macroscopic level, the adhesive failure occurred mostly in the late part of the annual ring, despite the cohesive failure in the early part of the annual ring for the soft-wood species. For oak as a hardwood, the most cohesive failures were detected at the shear areas of the specimens tested in a dry state.

To precisely specify the mechanism of failure, electron microscopy (SEM) was performed to observe the microscopic structure of the wood at the FRP/wood interphase region. For the softwood species, the adhesion failure did not show the existence of structural tracheid elements in the early parts of the annual rings. Nevertheless, the existence of ray elements filled with resin was observed (Figure 7); a deeper penetration of the adhesive was observed due to their perpendicular orientation to the application area, which was wetted by the adhesive. This clearly indicates that the existence and quantity of rays partake in the tensile-shear strength of the softwood species.

For the hardwood species, a good adhesive penetration into the lumina of all the conductive elements (vessel, libriform) was observed. This phenomenon was proven by a higher wood-failure percentage for the specimens tested in a dry state after a hygrothermal

Table 5: Resulting values of decreasing strength after exposing the test samples to different exposure criteria

\begin{tabular}{|l|c|c|c|c|c|}
\hline \multicolumn{1}{|c|}{ Exposure } & \multicolumn{5}{|c|}{ Decreasing-strength and wood-failure values (\%) } \\
\hline Standard requirements for beech & A1 & A2 (wet) & A3 (dry) & A4 (wet) & A5 (dry) \\
\hline Oak/CFRP (WF) & $10 \mathrm{MPa}$ & -40 & -20 & -40 & -20 \\
\hline Oak/GFRP (WF) & $9.3(98)$ & $-34.3(45)$ & $-6.0(73)$ & $-21.1(93)$ & $-6.4(93)$ \\
\hline Pine/CFRP (WF) & $8.6(100)$ & $-20.8(59.2)$ & $-0.5(98.3)$ & $-18.0(70.8)$ & $-4.6(100.0)$ \\
\hline Pine/GFRP(WF) & $8.3(100)$ & $-29.7(98)$ & $7.5(100)$ & $-29.7(70)$ & $13.0(100)$ \\
\hline Larch/CFRP (WF) & $7.9(100)$ & $-29.3(95.0)$ & $1.9(98.3)$ & $-29.5(70.8)$ & $6.1(91.7)$ \\
\hline Larch/GFRP (WF) & $8.3(97.0)$ & $-22.0(22.5)$ & $28.0(60.0)$ & $-22.3(38.0)$ & $2.9(86.0)$ \\
\hline Spruce/CFRP (WF) & $7.9(92.5)$ & $-24.7(0)$ & $-1.4(46.7)$ & $-28.6(56.3)$ & $12.1(78.3)$ \\
\hline Spruce/GFRP (WF) & $8.1(100)$ & $-36.8(100)$ & $-6.5(84)$ & $-22.3(74.0)$ & $-1.1(85.0)$ \\
\hline
\end{tabular}


J. VANĚREK et al.: DURABILITY OF FRP/WOOD BONDS GLUED WITH EPOXY RESIN

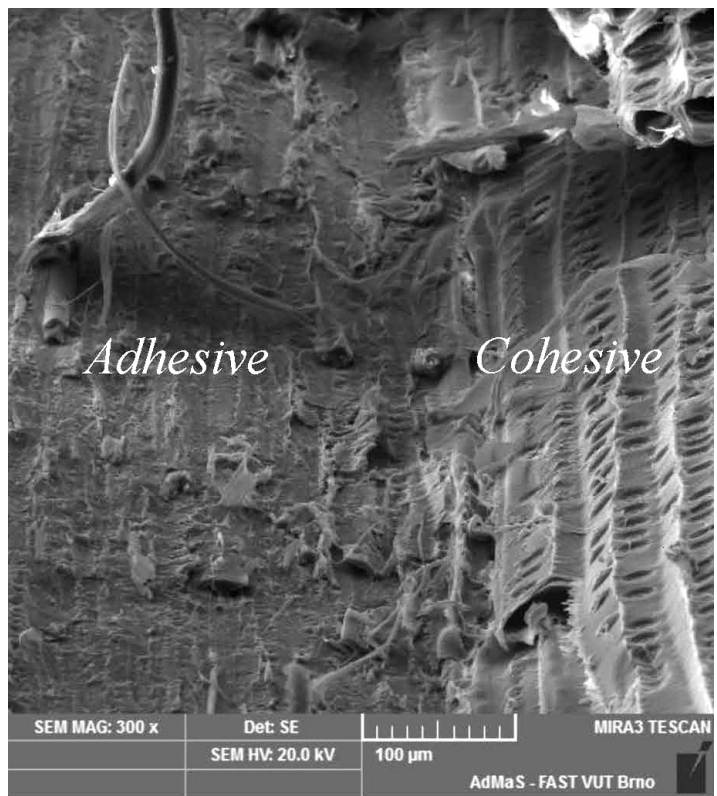

Figure 7: SEM micrograph of the border between early and late larch wood, different types of failure, magn. 300x

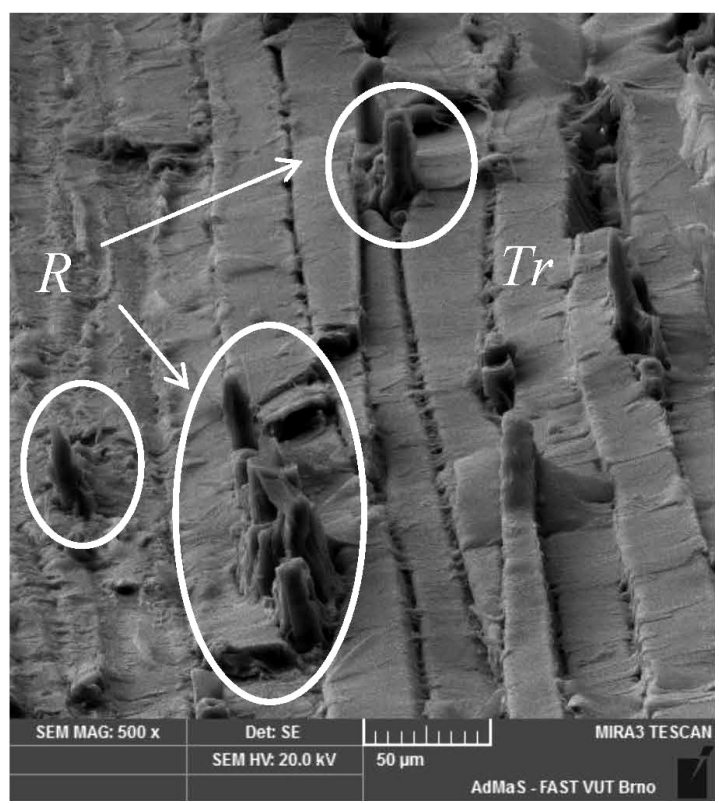

Figure 8: SEM micrograph, typical existence of rays (R) and tracheids (Tr) filled with resin, FRP/pine, magn. 500x

exposure. Despite this, the proper penetration of the adhesive into the lumina did not show a positive effect on the durability for the A2 and A4 condition classes.

\section{CONCLUSIONS}

The durability of FRP/wood bonds with different wood adherents was established using accelerated durability tests. According to the EN standard (declared for the beech/beech bond), all the tested samples of GFRP and CFRP fabrics met the standard criterion

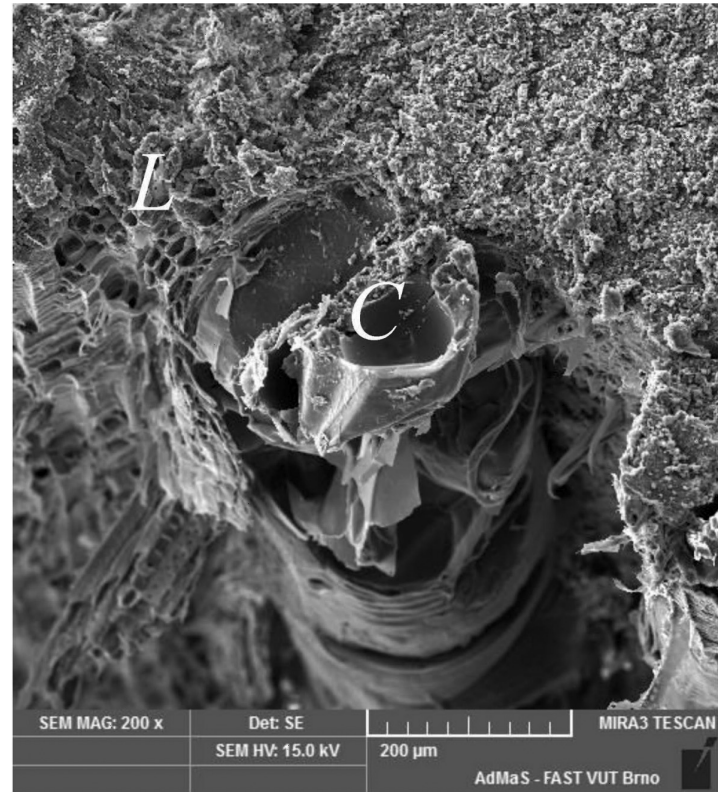

Figure 9: SEM micrograph of adhesive failure for FRP/oak, existence of the adhesive in the lumina of vessels (V) and libriform (L), magn. $200 \times$

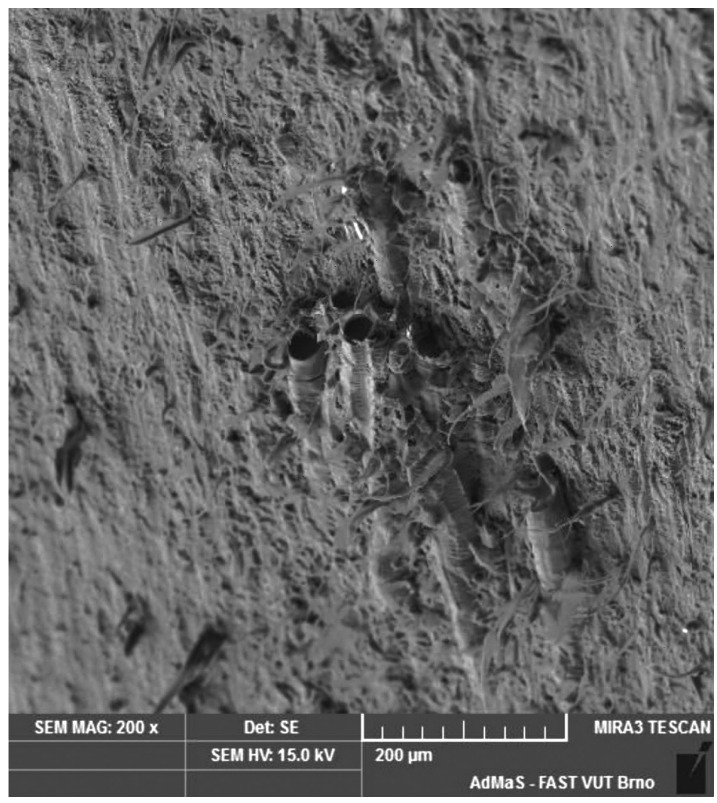

Figure 10: SEM micrograph of adhesive failure for FRP/oak, existence of cohesive failure of vessels, predominant adhesive failure of the FRP/oak bond line, magn. 200x

regardless of the wood species as the adherent. The wood species did not affect the durability of the FRP/wood bonds. The achieved strength for all the tested specimens in the conditions with a thermal exposure (A4, A5) was not significantly different from the one achieved in the conditions without a thermal exposure (A2, A3). Therefore, the inability of epoxy to withstand the volume changes of a wood adherent plays a more dominant role than the temperature influence on a possible resin degradation. The wood failure percentage proved to be a better 
means to assess the durability of bonded specimens compared to strength-loss aspects.

The principle of a good adhesion of the FRP/wood bonds via a mechanical interlocking process was considered for the experimental work. The size of the pores is dominant for the permeability of the adhesive into the cell lumina. Therefore, the surface roughness, porosity and size distribution of pores for all the tested wood samples were analyzed. The dependency between the porosity and the FRP/wood bond durability was not proven. The spruce wood having the highest porosity did not exhibit the lowest drop in the strength, or even the biggest value of the cohesive failure. Furthermore, the FRP/wood durability of all the tested softwoods showed no dependency on the pore-size distribution. According to the laser confocal microscopy analysis, it was found that good durability of the FRP/pine wood bonds exhibits a good relationship with the parameters of the surface roughness. A plain surface and elimination of any debris on the surface allow proper adhesive wetting.

All the results showed that the mechanical interlocking of the FRP/wood bond does not have the dominant role anticipated; on the contrary, the chemical bonds of the adhesive contribute to the higher durability of the epoxy/wood bonds. This is because an interpenetrating polymer (adhesive) network occurs in the cell walls and in the mesopores between the cellulose fibers in the cell walls. A proper application technique, ensuring a proper diffusion of the epoxy adhesive between the cellulose microfibrils in the cell walls seems to be necessary for more durable FRP/wood bonds.

\section{Acknowledgment}

This paper was prepared with the financial help of project TA04010425 "A complex system of special repair materials using secondary raw materials for industries" supported by The Technology Agency of The Czech Republic; and the internal project of specific research No. FAST-S-16-3772 "Research of an adhesive modification increasing the durability of FRP/wood bonds at moisture exposure" supported by Brno University of Technology, Faculty of Civil Engineering.

\section{REFERENCES}

${ }^{1}$ B. S. Trimble, Durability and mode-I fracture of fiber-reinforced plastic (FRP)/wood interface bond, Doctoral dissertation, West Virginia University, 1999, 192

${ }^{2}$ H. V. S. Ganga Rao, Sawn and laminated wood beams wrapped with fiber reinforced plastic composites, Wood Design Focus, 8 (1997) 3, 13-18

${ }^{3}$ D. J. Gardner, J. F. Davalos, U. M. Munipalle, Adhesive Bonding of Pultruded Fiber-Reinforced Plastic to Wood, Forest Products Journal, 44 (1994) 5, 62-66

${ }^{4}$ G. M. Raftery, A. M. Harte, P. D. Rodd, Bond quality at the FRPwood interface using wood-laminating adhesives, International Journal of Adhesion \& Adhesives, 29 (2009) 2, 101-110, doi:10.1016/j.ijadhadh.2008.01.006

${ }^{5}$ J. P. Alexander, S. M. Shaler, D. J. Gardner, Evaluating wood/FRP bond durability through chemical kinetics, Proc. of Wood Adhesive, Madison WI, 2000, 289-299

${ }^{6}$ M. Plötze, P. Niemz, Porosity and pore size distribution of different wood types as determined by mercury intrusion porosimetry, European Journal of Wood and Wood Products, 69 (2011) 4, 649-657, doi:10.1007/s00107-010-0504-0 